Article

\title{
Classroom Learning and the Perception of Social Responsibility Amongst Graduate Students of Management Accounting
}

\author{
Francisca Castilla-Polo*(D), María Consuelo Ruiz-Rodríguez, Alonso Moreno(D, \\ Ana Licerán-Gutiérrez ${ }^{\mathbb{D}}$, Macario Cámara de la Fuente, Eva Chamorro Rufián \\ and Manuel Cano-Rodríguez $\mathbb{D}$
}

Financial Economy and Accounting Department, School of Social and Juridical Sciences, University of Jaén, Campus Las Lagunillas, s/n, D-3, 23071 Jaén, Spain; mcruiz@ujaen.es (M.C.R.-R.); alonso.moreno@ujaen.es (A.M.); aliceran@ujaen.es (A.L.-G.); mcamara@ujaen.es (M.C.d.l.F.); echamo@ujaen.es (E.C.R.); mcano@ujaen.es (M.C.-R.)

* Correspondence: fpolo@ujaen.es; Tel.: +34-953-212-496

Received: 22 July 2020; Accepted: 28 August 2020; Published: 31 August 2020

check for updates

\begin{abstract}
This study analyzes how learning about social responsibility (SR) can modify the perceptions of university students about the importance of responsible behavior on the part of companies. To this end, a questionnaire was designed and administered to Management Accounting students before $(n=128)$ and after $(n=71)$ receiving two training activities on SR. The descriptive results obtained testify to the importance of SR in the views of the sampled students, both before and after receiving the specific learning in SR. In this latter moment, students demonstrated a vision highly committed to the need for SR to be part of the economic agenda. The results also show that there was a significant change in the perception of SR and its implications in terms of benefits and costs before and after receiving the training. All of this suggests that SR training has partially modified students' perceptions of SR. This paper provides important insights that could be leveraged by university and business school managers for the purpose of designing or modifying curricula related to SR. At the same time, it evaluates the potential of SR learning as a tool for modifying attitudes.
\end{abstract}

Keywords: social responsibility; higher education; learning; management accounting; sustainable development goals (SDGs)

\section{Introduction}

There is a growing demand for social responsibility (SR) to occupy a prominent place within university studies [1] and, especially, within business qualifications. Thus, the training of future executives, managers, and heads of companies/organizations should take into account the incorporation of such content, so that students understand that along with economic objectives, social and environmental objectives should also be considered. The students of today will be the managers and politicians of tomorrow [2] and a new generation of leaders concerned with business and society at the same time [3]. How SR is dealt with in the business sphere will not only affect companies but also society as a whole [4]. All of the above is affected by a context where financial scandals and unethical management practices in business have drawn attention to the role of university institutions with regard to the ethical and sustainable behavior of the professionals they are training.

Given its voluntary nature, it is prudent to consider the possible benefits and costs of incorporating SR in company decisions. Indeed, cost-benefit analysis can be applied to any type of decision, including investment in SR [5]. The accounting discipline plays a decisive role in helping to understand, analyze, 
and interpret the role of companies as economic, social, and environmental actors [6]. Soderstrom et al. [7] conclude that there are many opportunities to leverage management accounting within the area of sustainability pursuant of managing businesses in ways which recognize the importance of objectives beyond profit maximization.

The Principles for Responsible Management Education (PRME), developed in 2007 under the coordination of the United Nations Global Compact in conjunction with different academic institutions, are valuable evidence of the recent interest in the education-SR binomial. In Spain, 26 universities and business schools have already signed up to these six principles. In fact, the report Corporate Social Responsibility, Sustainable Development, and the Education and Training System [8] (p. 39) offered a conclusion some time ago about the value of the PRME in "making possible a type of teaching and research congruent with the new requirements of corporate social responsibility and the principles and values of sustainable development". However, Parkes [9] considers that the panorama of their integration is heterogeneous, finding institutions actively committed against others that have not yet joined this "journey".

Based on the conviction that university business students should be familiar with the SR concept and apply it to their future professional projects, we questioned their perceptions of this concept. To date, studies have shown a generalized lack of knowledge about SR [10-12], which is why Lämsä et al. [13] demanded more empirical research on this subject. For Alonso-Almeida et al. [14] little progress has been made since then (referring to the previous work), and research on attitudes to SR within the field of education is still in its infancy.

According to McDonald [15] there are three main lines of SR-education research: descriptive, prescriptive, and analytical. The first includes fundamental research that values the formative offer in SR, the second concerns how to approach this type of teaching from a methodological point of view. Finally, the analytical perspective focuses on if, and the extent to which, SR training changes the attitudes and perceptions of students. Following Deer and Zarestky [16], business education would benefit from better, more effective methods to address SR education, although they must achieve a change in attitudes, which is why we combine prescriptive and analytical lines in what follows.

Our work involves questioning how SR is understood by university students and their perceptions, but also analyzing its potential modification after learning through two different methods: a generic video conference on the concept and a specific training day focused on the United Nations Sustainable Development Goals (SDGs). Specifically, we propose to analyze how, and in what sense, basic training received on the concepts, dimensions, and tools for SR management alters students' opinions. There are somewhat equivocal results concerning the effects produced by SR training. There are positive results in this respect [11,17-19], but there is also neutral evidence suggesting that SR training may not alter students' perceptions [20] or may depend on the country of origin in the case of Peppas [21].

From a methodological point of view, two ad hoc questionnaires have been designed to reveal the perceptions of university students both prior to and after receiving specific training. Both will be analyzed to find out the possible changes experienced when presented with SR and the SDGs, as well as to obtain conclusions on the suitability of their learning within the university classroom. The sample is constituted by 128 and 71 students in each of the questionnaires, respectively, from the University of Jaén, pursuing different Management Accounting subjects taught within the business degrees of the Faculty of Social and Legal Sciences.

The remainder of the paper is structured as follows. Section 2 provides a review of the literature on SR and its implications for university business students. In Section 3, we define the methodology, followed by presenting and discussing the results in Section 4 . Finally, Section 5 concludes and provides suggestions for future research in this domain.

\section{Social Responsibility in University Classrooms}

The perception of SR by university students is a topic that has been recently explored to fundamentally investigate the potential and plausible behaviors of tomorrow's decision-makers 
and change-makers. Reviewing the salient literature (Appendix A) suggests that extant knowledge regarding university students' attitudes towards SR is still in a developmental phase $[14,19,22,23]$. Indeed, a generalized lack of knowledge and training in SR among university students can be deduced $[11-13,24,25]$. There is also evidence to suggest that students and other groups perceive a need for learning about SR [26,27].

It is common to study students' perceptions of SR and to characterize the variables that determine these perceptions, rather than to go into detail on tools that may facilitate the modification of perceptions. Thus, studies that have analyzed the existence of differences in SR perceptions according to gender, course, and field of study are recurrent. Studies suggest that women tend to show more interest in and/or engage more frequently in SR activities [28-31]. Similarly, the awareness of senior students is often higher than that of those who are starting their studies [29,30]. Additionally, it is often found that the awareness of university students on aspects connected with SR depends on the degree they are taking. Thus, in Spain it has been revealed that degrees related to economics and business sciences create the most awareness of social aspects such as SR [29,32,33]. At an international level, although there is evidence of divergence, degrees in economics, finance, and information management also stand out as creating the most awareness of social aspects such as SR in some universities [26].

It seems logical to think that the training that university students receive on SR can produce changes in their perceptions, but to date the results obtained in the small number of studies that have been undertaken on this issue are not fully conclusive [11,20,31]. There are positive results [11,17-19] as well as some evidence that suggests no significant relationship [20]. If we focus on the type of SR training, the extant literature does not always analyze formal training, it may be informal training [11,34-36], which may also result in numerous benefits for students such as increased commitment to social issues to the detriment of economic issues [37] and improved socially responsible decision-making.

In general, we appreciate that the university environment is concerned about social and environmental issues $[10,26,29,38,39]$, which justifies our interest in this field of research. It can even be appreciated that the way the university is managed internally will affect its concept of SR [25].

In the Spanish case, there are some studies based on the impact that SR training produces on women; their results show that the effect of these variables is greater and will positively influence decision-making $[11,14,20,40]$. In fact, together with gender, grade, and course, these are two different variables that will influence the perceptions of students at the Spanish level, highlighting the business and accounting degree as the most aware of social aspects [29]. Finally, another variable that has been studied in a general way due to its influence on the perception of SR is the student age, as there is a generalized idea that it has a positive influence on SR perception $[20,30,31,41]$.

The SDGs occupy a prominent place in the field of SR; in fact, they cover general SR principles in all areas: business, family, and government, among others. The effort made by the United Nations to achieve sustainable education based on the implementation of the SDGs and their promotion is evident from the World Conference on Education for All (EFA) in Jomtien in 1990, the World Education Forum in Dakar in 2000, the United Nations Decade of Education for Sustainable Development in Johannesburg in 2002, Agenda 2030 in 2015 in New York, and the successive High Level Political Forums in 2016, 2017, 2018, and 2019 at the United Nations headquarters in New York, among other events. In Spain, the Conference of Spanish University Rectors (CRUE) created a working group in 2002 with the purpose of ensuring that the concept of sustainable development and the achievement of the SDGs should guide curricula. Additionally, the Spanish Network for Sustainable Development (REDS), created in 2015 with the objective of raising awareness of the SDGs in Spanish society, public institutions, and the corporate world, prepared a specific report Towards Education for Sustainability (2019).

The importance of universities' commitment to the SDGs is the main focus of the SDSN Australia/Pacific report [42], with a reciprocal relationship established between the need for universities to implement SDGs and why the SDGs need universities. In fact, we highlight the work of the university as a trainer and facilitator of good management practices, providing knowledge that contributes to sustainable development and compliance with the SDGs [43,44]. In this sense, several authors highlight 
the importance of higher education in the training of business leaders who are aware of the importance of achieving the SDGs, such as Avelar et al. [45], Crespo et al. [37], Kolb et al. [46], and Weybrecht [47]. Avelar et al. [45] believe that implementing the SDGs requires that education is at the center of the strategy. There is a demand to improve aspects related to the training of university professors in SDG domains, the dissemination of information about these SDGs [48], the awareness of educators and business leaders about the dissemination of SDG information [45], and a need for a transversal approach for the development of the necessary competencies [49]. According to the latter authors, the development of competencies related to SDGs is a challenge for universities today given the low level of knowledge about them among their students.

Among the advantages of a university implementing the SDGs in its education, the SDSN Australia/Pacific report [42] highlights the possibility of defining itself as a responsible and globally committed institution, setting an example in society, and training students concerned about sustainability. Furthermore, it points out that the SDGs need universities, considering them as institutions that provide knowledge to implement and manage them and to raise awareness of their importance among future professionals. Interdisciplinarity in university education, within which disciplines focused on sustainability and SR are combined with other disciplines, may facilitate the achievement of SDGs [50].

Several studies (Appendix B) have focused on highlighting the fact that universities' actions are aimed at complying with SDG 4 "Guaranteeing equitable and quality education and promoting learning opportunities" [51,52]. In our case, the SDGs have been understood in their relationship with SR, justifying their presence in one of the two training activities. Materials and Methods should be described with sufficient details to allow others to replicate and build on published results.

\section{Materials and Methods}

\subsection{Sample and Data Collection}

As per the foregoing, business degree students have the ability to influence responsible and sustainable business practices, as they are likely to find themselves in management and decision-making positions in a few years' time. Specifically, the subjects related to Management Accounting are fundamental for developing the ability to make business decisions, as well as to evaluate the advantages and disadvantages of using SR within them. It is for this reason that our target population is students at the University of Jaén (Spain) who were studying the degrees and subjects shown in Table 1.

Table 1. Degrees and participating subjects.

\begin{tabular}{ccc}
\hline Degree & Subject & Year \\
\hline Business Administration and Management (BAM) & Management Accounting & 2 \\
Statistics and Business (S\&B) & Management Control & 2 \\
Business Administration and Law: joint degree (BAM + Law) & Management Accounting & 3 \\
Master of Business Administration (MBA) & Social Responsibility \& & 1 \\
\hline
\end{tabular}

In line with previous studies, a questionnaire was used to ascertain the perceptions of university students regarding SR $[11,24,35,38,53]$. Our study population was asked to collaborate by completing both an initial and final questionnaire.

The initial questionnaire was completed at the beginning of the second term of the 2018/2019 academic year in a face-to-face and anonymous way during one of the sessions of each degree program. Its objective was to obtain information on the pre-existing knowledge that university students had about SR, differentiating between those who claimed to be familiar with this concept and those who were not. The first group was asked for information on the ways in which they had gained knowledge, the importance of different generic SR initiatives in companies, and the cost-benefit ratio of SR business 
behavior. The questionnaire consists of a total of 16 questions, of which 4 are general personal data questions (academic degree, date of birth, gender, and range of monthly incomes perceived by the participants) to locate the research and a fifth question to discriminate whether or not the concept of $\mathrm{SR}$ is known. In the case of knowing the concept of SR, 6 additional questions had to be answered, and otherwise, 5 more questions were answered. For the group of students who stated that they were not familiar with SR, a question was posed indirectly raising this concept (SR) and, in a hypothetical way, the importance of SR business initiatives and the cost-benefit relationship. Therefore, the initial questionnaire was carried out by 128 students, of which 67 were men, compared to 61 women.

Table 2 shows the profile of the students who responded to the initial questionnaire. That is, 128 students ( $52 \%$ men and $48 \%$ women) on four degree programs ( $54 \%$ BAM, $17 \%$ S\&B, $16 \%$ MBA, and $13 \%$ BAM + Law).

Table 2. Profile of respondents to the initial questionnaire.

\begin{tabular}{ccccccc}
\hline Degree & \multicolumn{2}{c}{ Men } & \multicolumn{2}{c}{ Women } & \multicolumn{2}{c}{ Total } \\
\hline BAM & 40 & $(31 \%)$ & 29 & $(23 \%)$ & 69 & $(54 \%)$ \\
S\&B & 8 & $(6 \%)$ & 14 & $(11 \%)$ & 22 & $(17 \%)$ \\
MBA & 8 & $(6 \%)$ & 12 & $(9 \%)$ & 20 & $(16 \%)$ \\
BAM + Law & 11 & $(9 \%)$ & 6 & $(5 \%)$ & 17 & $(13 \%)$ \\
Total & 67 & $(52 \%)$ & 61 & $(48 \%)$ & 128 & $(100 \%)$ \\
\hline
\end{tabular}

The final questionnaire was also completed in class (four months later, in May 2019) by those students who fulfilled two conditions: having completed the initial survey and having participated in the SR training. This questionnaire was the same for all participants as they had all received SR training. It began by asking about the importance attributed to SR, including its topicality, its relevance for certain types of companies, as well as some statements dealt with in the learning process. Then, the advantages and disadvantages of SR integration in business management were listed again to discern if and the extent to which students' views in this respect had been modified because of learning. Questions were also put forward to ask students how, in their opinion, SR content should be integrated in the university context. In the final questionnaire, the number of women was 36, compared to 35 men, which made a total of 71 participants. The final questionnaire consisted of a total of 18 questions, 9 of which were intended to discover the degree of importance attributed to the concept of SR, and 5 questions were directed to discover how SR can be methodologically integrated into the different subjects of the degrees that are part of our study.

Table 3 presents the profile of those individuals who answered the final questionnaire. As indicated, participation in this second questionnaire implies having completed the initial questionnaire, as well as having taken part in the training activities: the workshop and videoconference. The sample size was reduced compared to the first round: the MBA students were not included here because they were subjected to a different learning exercise (passive and active, through SR sessions given by different speakers). The final sample was constituted by 71 students ( $49 \%$ men and $51 \%$ women) undertaking 3 degrees (72\% BAM, 15\% S\&B, and 13\% BAM + Law).

Table 3. Profile of respondents to the final questionnaire.

\begin{tabular}{ccccccc}
\hline Degree & \multicolumn{2}{c}{ Men } & \multicolumn{2}{c}{ Women } & \multicolumn{2}{c}{ Total } \\
\hline BAM & 26 & $(37 \%)$ & 25 & $(35 \%)$ & 51 & $(72 \%)$ \\
S\&B & 4 & $(6 \%)$ & 7 & $(10 \%)$ & 11 & $(15 \%)$ \\
BAM + Law & 5 & $(7 \%)$ & 4 & $(6 \%)$ & 9 & $(13 \%)$ \\
Total & 35 & $(49 \%)$ & 36 & $(51 \%)$ & 71 & $(100 \%)$ \\
\hline
\end{tabular}

Regarding the scales used in both questionnaires, we highlight two types. On the one hand, the graduation scale, in which the degree of agreement with a statement is revealed and, on the other 
hand, a yes-no response scale to select aspects, such as the advantages and disadvantages of SR for companies. In the case of the items selected in each question, they were deducted according to the proposed literature review that has been carried out.

\subsection{SR Learning}

As indicated, learning about SR forms the basis of the research in this study. Thus, it has been important not only to understand the perceptions of university students in this respect, but also how these perceptions are modified when they receive learning consisting of the following two activities.

The first activity was a training day on the SDGs in April 2019 by a member of the Agenda 2030 High Commission. The SDGs consist of 17 goals and 169 targets that are broader in scope and go beyond the Millennium Development Goals (MDGs), as they cover the three dimensions of sustainable development: economic growth, social inclusion, and environmental protection. Their ultimate goal is to achieve sustainable development, and they therefore target a wide range of recipients. The SDGs require action by all actors, governments, business, and civil society. The speaker covered the following: justification of the SDGs, description of the SDGs, and implications derived from their adoption. Finally, a question-answer session gave students the opportunity to resolve any doubts.

The second activity was of a more general nature and presented SR through a video conference given to students by an expert in the field. In it, all the questions related to the definition of SR and its management were presented in a more directed way. The concept, dimensions, management systems of SR, and social disclosure were contents that integrated this videoconference to form a complete vision of the involvement of SR within business management.

Figure 1 summarizes the methodological procedures.

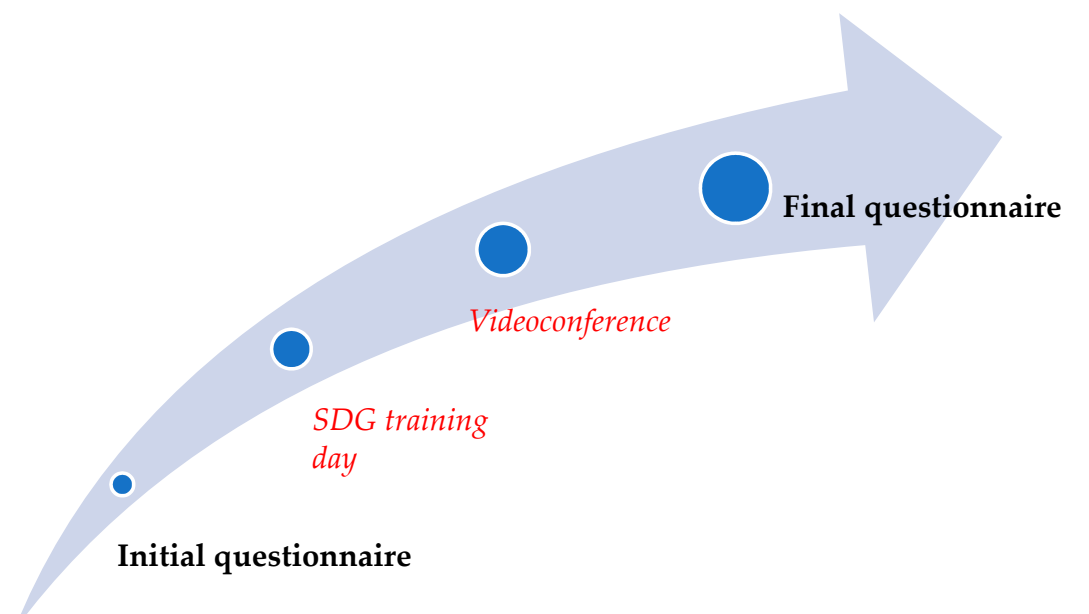

Figure 1. Methodological design.

As a fundamental issue from a methodological point of view, we emphasize that the six PRME (Figure 2) have been introduced as a framework within the design of this research. The PRME form the setting for our methodological design, offering a global integrative approach to the whole design process carried out in this research. 

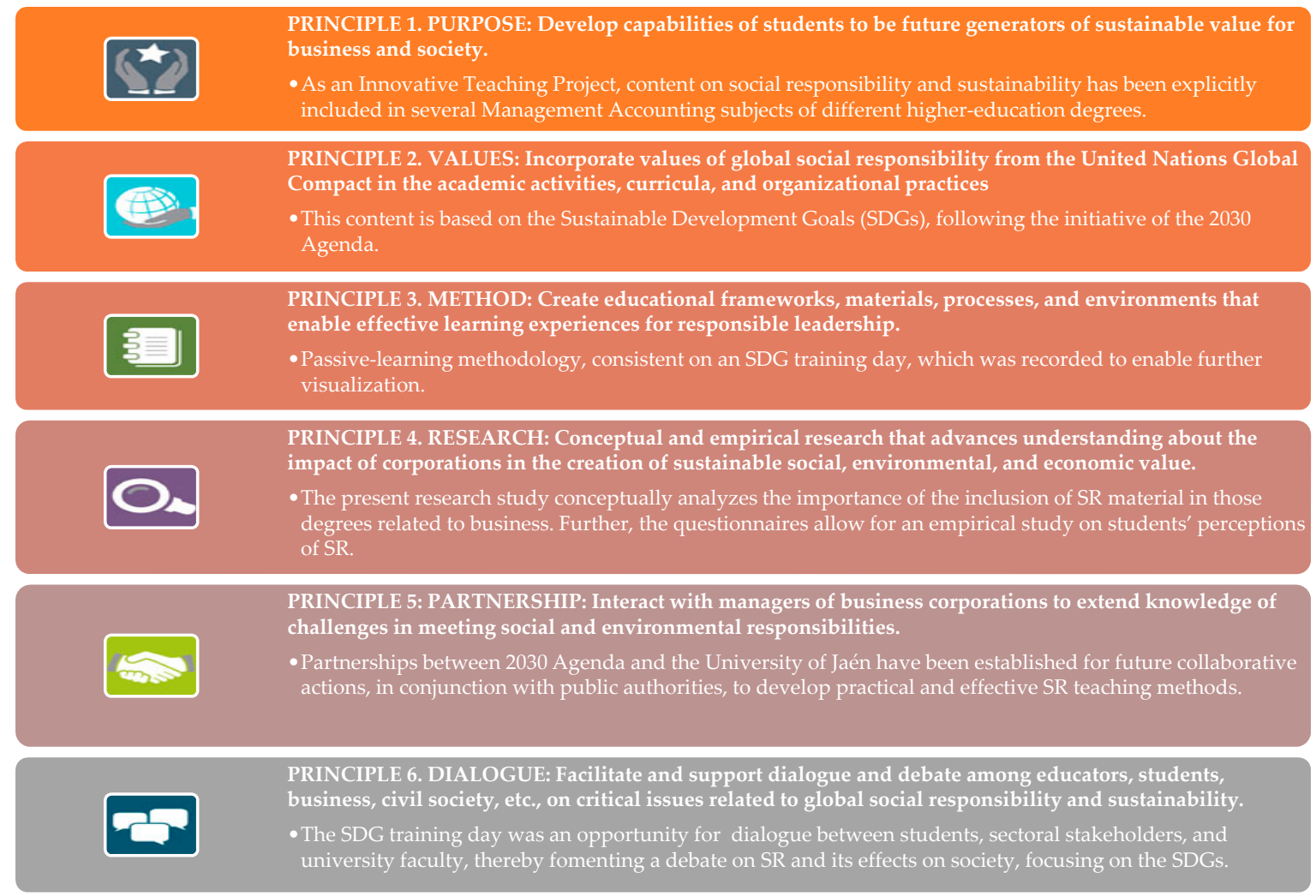

Figure 2. The six principles for responsible management education (PRME). Source: Prepared by the authors on the basis of PRME [54].

\section{Results}

\subsection{Initial Questionnaire: Descriptive Results}

Table 2 shows the profile of the students who responded to the initial questionnaire. $62 \%$ of respondents said they were familiar with (38\% were unfamiliar with) the concept of SR. This key question served to discriminate against the rest of the questionnaire. We show below the differentiated results for each group of students.

\subsubsection{Students Familiar with SR}

Of the 79 (62\%) respondents who said they were familiar with the concept of SR, 47\% said they had learned about it through the Internet, 36\% through subjects in their curriculum, 30\% through TV, radio, or print ads, $16 \%$ through lectures, $11 \%$ through training courses, and $5 \%$ through other channels (such as high school subjects, final degree projects, books, family, or friends). These results partially coincide with those found by Díaz and Facal [35], who highlight that students' knowledge of SR had been acquired in non-regulated training courses. Tormo-Carbó et al. [20] defend life experiences as alternatives for acquiring SR training, while Kolodinsky et al. [12] consider ideology to be the forerunner of SR training. Eweje and Brunton [40] hold work experience responsible as the best way to learn about SR. Ng and Burke [55], Lämsa et al. [13], and Luthar and Karri [17] consider that educational level is the most important determinant of SR perceptions.

Continuing with the group of students who claim to be familiar with SR, Table 4 shows the relevance that respondents ascribed to different SR initiatives. Sixty-five percent believed that the participation of companies in environmental recovery/support programs (waste collection, reforestation, recycling) is very relevant, an aspect also highlighted by Asrar-ul-Hap et al. [56], Vázquez et al. [19], and Yuan et al. (2013). Participation in programs for labor equality was also considered very relevant 
(56\%) [56]. The least relevant initiative among those consulted was the participation of companies in community development programs (such as event sponsorship) $(25 \%)[10,36]$. It is noteworthy that environmental and employee domains of SR dominate in terms of perceived relevance, even though community initiatives may be most associated with the birth of this concept. Larrán et al. [29] found a greater interest in the social and environmental dimensions, including actions to favor and improve the community in the former.

Table 4. Relevance of different SR initiatives (\%).

\begin{tabular}{|c|c|c|c|c|c|c|}
\hline$n=79$ & NR & NVR & I & $\mathbf{R}$ & VR & DU \\
\hline $\begin{array}{l}\text { Participation of companies in solidarity programs, understood in a broad } \\
\text { sense (e.g., aid to the most in need and to groups at risk of exclusion) }\end{array}$ & 1 & 4 & 5 & 53 & 37 & 0 \\
\hline $\begin{array}{l}\text { Participation of companies in environmental recovery/support programs } \\
\text { (e.g., waste collection, reforestation, and recycling) }\end{array}$ & 0 & 1 & 4 & 30 & 65 & 0 \\
\hline $\begin{array}{l}\text { Participation of companies in equality programs } \\
\text { (e.g., gender non-discrimination and conciliation initiatives) }\end{array}$ & 0 & 1 & 8 & 33 & 56 & 3 \\
\hline $\begin{array}{l}\text { Involvement of businesses in community development programs } \\
\text { (e.g., event sponsorship) }\end{array}$ & 1 & 8 & 14 & 51 & 25 & 1 \\
\hline
\end{tabular}

NR: Not at all relevant; NVR: Not very relevant; I: Indifferent; R: Relevant; VR: Very relevant; DU: Does not understand.

Going deeper into the implications of SR for the group that claimed to be familiar with SR, Table 5 summarizes opinions about the main advantages for companies that pursue SR objectives. Fifty-four percent believe that the achievement of a better society and a cleaner environment is highly relevant in line with the assessment of SR initiatives in the environmental sphere in the previous question [56,57]. The least relevant advantage among those consulted is the return to society of part of what is received from it (27\%), also corroborating the lower interest in SR actions in the community [58]. The achievement of various economic benefits, including reputation improvement, was considered relevant by $47 \%$ of respondents [29], but very relevant to only $37 \%$, which places it in second place.

Table 5. Main advantages for companies that pursue SR objectives (\%).

\begin{tabular}{|c|c|c|c|c|c|c|}
\hline$n=79$ & NR & NVR & $\mathbf{I}$ & $\mathbf{R}$ & VR & DU \\
\hline Achieving a better society and a cleaner environment & 1 & 0 & 8 & 37 & 54 & 0 \\
\hline $\begin{array}{l}\text { Achieving different economic benefits, among which it stands out to get } \\
\text { a better reputation }\end{array}$ & 6 & 0 & 10 & 47 & 37 & 0 \\
\hline Return to society part of what has been received from it & 3 & 6 & 9 & 54 & 27 & 1 \\
\hline
\end{tabular}

NR: Not at all relevant; NVR: Not very relevant; I: Indifferent; R: Relevant; VR: Very relevant; DU: Does not understand.

Table 6 shows what the main disadvantages would be for companies pursuing SR objectives. Twenty-nine percent estimated that the time and effort devoted to carrying out this type of responsible action is very important [34,59], followed by the need for training in $22 \%$ of cases $[16,24,34,59]$ and the investment required to implement these actions in $10 \%$ of cases [34]. However, on this last issue, $54 \%$ of respondents considered it to be relevant.

Table 6. Main disadvantages for companies that pursue SR objectives (\%).

\begin{tabular}{|c|c|c|c|c|c|c|}
\hline$n=79$ & NR & NVR & I & $\mathbf{R}$ & VR & DU \\
\hline The amount of money allocated to cover social responsibility actions & 1 & 15 & 18 & 54 & 10 & 1 \\
\hline The time and effort dedicated to carrying out these types of responsible actions & 4 & 0 & 13 & 42 & 29 & 13 \\
\hline The need for training in the field of social responsibility & 0 & 18 & 15 & 42 & 22 & 4 \\
\hline
\end{tabular}

NR: Not at all relevant; NVR: Not very relevant; I: Indifferent; R: Relevant; VR: Very relevant; DU: Does not understand. 


\subsubsection{Students not Familiar with SR}

We will now turn to the comments of those respondents (49) who stated that they were not familiar with the concept of SR (38\%). They were asked about issues related to this concept in an indirect way. Firstly, they were asked whether they thought it was appropriate for companies to carry out voluntary actions to improve society and the environment (definition provided by the European Commission, 2011); $92 \%$ replied positively, $2 \%$ negatively, and $6 \%$ perhaps.

Table 7 below shows the relevance that this subset of the sample attributed to different SR initiatives. Eighty percent believed that business participation in equality programs is highly relevant, followed by participation in recovery/environmental support activities $(78 \%)[19,53,56]$. The least relevant initiative was the participation of companies in community development programs (such as event sponsorship) (22\%) [10,36] and business solidarity programs (37\%). These results are reasonably similar to those obtained from the group who were familiar with the concept of SR, although SR in the field of work occupies first place in this group. Surprisingly, in the results obtained by Alonso-Almeida et al. [14], students placed improvement of environmental conditions in the penultimate position of the list elaborated by those authors, something worrying in their opinion, which could be justified by lack of knowledge of the value of SR.

Table 7. Relevance of different SR initiatives (\%).

\begin{tabular}{|c|c|c|c|c|c|c|}
\hline$n=49$ & NR & NVR & I & $\mathbf{R}$ & VR & DU \\
\hline $\begin{array}{l}\text { Participation of companies in solidarity programs, understood in a broad } \\
\text { sense (e.g., aid to those most in need and to groups at risk of exclusion) }\end{array}$ & 0 & 2 & 8 & 53 & 37 & 0 \\
\hline $\begin{array}{l}\text { Participation of companies in environmental recovery/support programs } \\
\text { (e.g., waste collection, reforestation, and recycling) }\end{array}$ & 0 & 0 & 0 & 22 & 78 & 0 \\
\hline $\begin{array}{l}\text { Participation of companies in equality programs } \\
\text { (e.g., gender non-discrimination and conciliation initiatives) }\end{array}$ & 0 & 0 & 2 & 16 & 80 & 2 \\
\hline $\begin{array}{l}\text { Involvement of businesses in community development programs } \\
\text { (e.g., event sponsorship) }\end{array}$ & 2 & 2 & 24 & 49 & 22 & 0 \\
\hline
\end{tabular}

NR: Not at all relevant; NVR: Not very relevant; I: Indifferent; R: Relevant; VR: Very relevant; DU: Does not understand.

As with the respondents who stated that they were familiar with the SR concept, potential advantages and disadvantages of this type of action for companies were raised with this group.

Table 8 shows the perceived advantages for companies pursuing SR objectives. Fifty-five percent believed that achieving a better society and a cleaner environment is very relevant [56,57], followed by giving back to society a part of what companies' receive from it (41\%) [58]. The least relevant advantage among those consulted was the achievement of economic benefits (37\%) [59]. Here we do see differences, as the economic profitability of SR was not considered as the least relevant advantage by those students who were familiar with SR.

Table 8. Main advantages for companies that pursue SR objectives (\%).

\begin{tabular}{|c|c|c|c|c|c|c|}
\hline$n=49$ & NR & NVR & $\mathbf{I}$ & $\mathbf{R}$ & VR & DU \\
\hline Achieving a better society and a cleaner environment & 0 & 0 & 4 & 41 & 55 & 0 \\
\hline $\begin{array}{l}\text { Achievement of different economic benefits, among which it stands out } \\
\text { to get a better reputation }\end{array}$ & 4 & 4 & 12 & 43 & 37 & 0 \\
\hline Return to society part of what it receives from it & 0 & 2 & 16 & 41 & 41 & 0 \\
\hline
\end{tabular}

NR: Not at all relevant; NVR: Not very relevant; I: Indifferent; R: Relevant; VR: Very relevant; DU: Does not understand.

Table 9 shows the perceived disadvantages for companies pursuing SR objectives. Thirty-one percent considered that the need for training in the field of SR in the company itself was very relevant $[16,24,34,59]$, followed by the time and effort required $(24 \%)[34,59]$. The least relevant 
disadvantage was the money that such actions would cost (10\%) [34]. Again, here we also see differences between students who knew about SR and those who did not; although they surprisingly agreed that the economic cost of SR actions was the least relevant disadvantage.

Table 9. Main disadvantages for companies that pursue SR objectives (\%).

\begin{tabular}{|c|c|c|c|c|c|c|}
\hline$n=49$ & NR & NVR & $\mathbf{I}$ & $\mathbf{R}$ & VR & DU \\
\hline The amount allocated to cover social responsibility actions & 2 & 2 & 14 & 67 & 10 & 4 \\
\hline The time and effort dedicated to carrying out these types of responsible actions & 0 & 10 & 14 & 51 & 24 & 0 \\
\hline The need for training in the field of social responsibility & 2 & 8 & 16 & 41 & 31 & 2 \\
\hline
\end{tabular}

NR: Not at all relevant; NVR: Not very relevant; I: Indifferent; R: Relevant; VR: Very relevant; DU: Does not understand.

\subsection{Final Questionnaire: Descriptive Results}

Table 3 presents the profile of those individuals who answered the final questionnaire. Respondents were asked about the relevance they attributed to SR after taking part in the activities designed to provide training in this concept. This first question elicited importance on a Likert scale from 1 to 7 , where 1 denoted that SR is not at all relevant and 7 denoted that SR is very relevant; $44 \%$ assigned it a score of $5,31 \%$ a score of $6,20 \%$ a score of 7 , and $6 \%$ a score of 4 .

Table 10 shows the importance respondents attributed to various SR-related issues that had been addressed in the training activities. Ninety-one percent believed that it is important or very important for companies to integrate SR on a daily basis. Eighty-three percent thought that problems are important or very important to achieve sustainable development in the world. Seventy-nine percent believed that the interest of the Spanish government in SR is important or very important. Ninety-five percent thought that Agenda 2030 is important or very important for companies to be socially responsible in line with other studies $[44,48,51]$. These results support prevailing tendencies vis-à-vis the place and position of SR in the business world and politics.

Table 10. Importance of different SR issues (\%).

\begin{tabular}{|c|c|c|c|c|c|}
\hline$n=71$ & NI & SI & IN & $\mathbf{I}$ & VI \\
\hline The importance for companies to integrate social responsibility in their day-to-day business & 0 & 7 & 1 & 56 & 35 \\
\hline The existence of major challenges to achieving sustainable development in the world & 0 & 4 & 13 & 51 & 32 \\
\hline The government's interest, in this case Spain, in social responsibility & 1 & 6 & 14 & 42 & 37 \\
\hline $\begin{array}{c}\text { The role of sustainable development objectives (Agenda 2030) in making companies } \\
\text { socially responsible }\end{array}$ & 0 & 0 & 6 & 58 & 37 \\
\hline
\end{tabular}

NI: Not at all important; SI: Slightly important; IN: Indifferent; I: Important; VI: Very important.

Respondents were also questioned about the current state of affairs in terms of SR. Fifty-nine percent stated that it was a topical issue for everyone (business and society in general). Only $1 \%$ stated that SR was not a current issue. These results allow us to conclude on the opportunity of SR in a broad sense for the society-business binomial.

Looking in depth at the implications for management of SR in business contexts, respondents were asked whether they considered SR to be particularly relevant for certain types of businesses. Eighty-three percent stated that it should be a concern for all companies, endorsing the need for university-business relations to be based on the transmission of knowledge about SR [23] as well as the relevance of SR for university business students.

With regard to the specific advantages of SR for companies, $85 \%$ considered that it increases environmentally responsible behaviors [57]; 70\% considered that it improves behavior in the society in which it is integrated; $61 \%$ considered that it improves relations with their employees [56]; $48 \%$ considered that it benefits image and corporate reputation [59]; $41 \%$ considered that it improves behavior with suppliers and customers, among other groups; and none of those surveyed believed that SR does not represent an advantage. 
In terms of the disadvantages that SR can entail for companies, $72 \%$ considered the financial outlay of SR measures; $32 \%$ considered internal organizational problems involved in implementing SR measures to be a disadvantage; and $20 \%$ considered competitive problems to be a disadvantage, for example, disadvantages in comparison with companies that are socially responsible. Only $8 \%$ considered that SR only brings benefits.

In addition to questions relating to SR in companies, this second questionnaire was used to ask students about the most appropriate ways of incorporating SR into their university training. At first, respondents were asked to assess the extent to which their degree program had facilitated achievement of the competence "Knowing and understanding SR derived from business actions". On a scale of 1 to 7 , where 1 means no achievement and 7 means total achievement, $32 \%$ assigned a score of 6 , another $32 \%$ assigned a score of $5,23 \%$ a score of 4 , and only $6 \%$ a score of 7 .

Another topic discussed was how to introduce SR into the university environment. Eighty-seven percent believed that this is a topic that should be addressed in formal degree training. Only $4 \%$ believed that it should not be treated in a regulated manner. With regard to what type of courses SR should be included within, $58 \%$ believed that it should be included in a specific optional subject, while $27 \%$ defended a specific obligatory subject. Only $12 \%$ did not believe that it should be integrated in any way. These findings could be leveraged by program and course conveners in universities when they consider future training actions in SR.

Finally, respondents were asked about the extent to which they felt that SR would affect their future as academics in the field of business. On a scale of 1 to 7 , where 1 means that SR will have no impact and 7 means a high impact, 39\% assigned a score of $6,27 \%$ a score of 5 , and $17 \%$ a score of 7 .

\subsection{Cost-Benefit Analysis of SR after Classroom Learning}

Given the importance of cost-benefit analysis for Management Accounting students that constitute our study population, we address how benefits and costs have been impacted by the SR training.

We used McNemar's test to gauge whether the change in response in categorical variables after exposure of the sample to a treatment is significant (in this case, after learning about SR). In Table 11, the rows correspond to the initial responses, and the columns to the final responses (Exposed corresponds to dummy $=1$ (favorable), while Unexposed corresponds to dummy $=0$ (unfavorable)). The null hypothesis is that there are no differences in the behavior of individuals, the alternative being that there are differences.

Table 11. McNemar's test (initial questionnaire vs. final questionnaire).

\begin{tabular}{cccccc}
\hline & Cases $\backslash$ Controls & Exposed & Unexposed & Total & $\begin{array}{c}\text { McNemar's Chi2 } \\
\text { (Prob }>\text { Chi2) }\end{array}$ \\
\hline \multirow{3}{*}{ Benefit of improving society } & Exposed & 43 & 8 & 51 & $5.44^{* *}$ \\
& Unexposed & 1 & 1 & 2 & $(0.0196)$ \\
& Total & 44 & 9 & 53 & \\
\hline \multirow{3}{*}{$\begin{array}{c}\text { Benefit of improving } \\
\text { reputation }\end{array}$} & Exposed & Exposed & Unexposed & Total & \\
& Unexposed & 7 & 23 & 45 & $8.53^{* * *}$ \\
& Total & 29 & 1 & 8 & $(0.0035)$ \\
Cost of inconvenient & Exposed & Exposed & Unexposed & Total & \\
organizational complexity & Unexposed & 3 & 23 & 40 & $15.38^{* * *}$ \\
& Total & 20 & 10 & 13 & $(0.0001)$ \\
\hline
\end{tabular}

*** indicates $p$-value below 0.01 ; ** indicates $p$-value below 0.05 .

Analyzing the different costs and benefits proposed to the participating students, the results show that there are significant differences in the assessment of the benefits of improving society and improving reputation. The opinion of the students about the other advantage of SR that was included in 
the questionnaire, the fact that taking SR actions the entities could somewhat rewarding the society for the benefits they receive from the society, has not been found to be significantly affected. To elaborate, after receiving SR training, significantly more students believed that these two benefits arose.

With regard to the cost of inconvenient organizational complexity, as can be seen in Table 11, this change of opinion is also statistically significant; i.e., after students had undertaken learning in SR, they became more aware of the implications that it triggers for companies.

\section{Discussion and Conclusions}

Considering the importance for future business professionals to maintain a social and ethical commitment, SR emerges as an important subject in the university environment. The PRME [54] promote a global network based on six principles to promote sustainability and the commitment of institutions vis-à-vis management training, which incorporates universal values within the respective training programs and/or research activities. In this context, the PRME have been implemented in this study within a methodological design aimed at understanding the importance attributed to SR by university business students. Two SR training activities were designed and an assessment was undertaken concerning how perceived importance of SR changed after students were exposed to learning about SR. The implications for management and university training were also elicited from respondents.

Our results show that SR was considered relevant by university students based on their pre-existing knowledge and values, both directly and indirectly (for those who were not initially familiar with the concept). This is particularly the case with respect to environmental and labor dimensions and, to a lesser extent, social and community dimensions. The advantages of SR perceived by students are associated with the environment, society in general, and to a lesser extent, with various economic benefits, such as corporate reputation. As for the disadvantages, the economic outlay required for SR is the least important, but there are organizational problems of time, effort, and necessary training. In view of these results, we can conclude that the vision of SR implementation held by students who did not receive training in SR is not very focused on its business effects but rather on its benefits for society or "as a whole".

If we compare these results with the final evaluation of the students, it can be seen that SR, both from a global point of view and from business and political points of view, is considered to be very relevant. Likewise, students understand that it is a concept applicable to all types of companies, and that it implies joint work by all agents, not just companies, pursuant of achieving sustainable development in accordance with the SDGs. With regard to the cost-benefit ratio, significant differences were detected between students' assessments in the initial and final questionnaires. For example, the perceived importance of reputation increases as one of the business benefits of SR. However, students' assessment of the benefits of responsible corporate behavior in society is also important. On the cost side, potential issues in terms of organizational problems involved in SR business management were recognized to a greater extent according to the responses to the final questionnaire.

Accordingly, the results show that SR training can change the perceptions of university business students, making them understand the cost-benefit ratio of SR in a different way and broadening the focus. In any case, the reinforcement achieved was always positive because training was not found to cause less interest in SR or in the implications of the cost-benefit analysis it entails.

The main limitation of our study is the small sample size. If future work employed a larger sample, it would allow generalization of results to broader university contexts. Further, a longitudinal approach would allow us to observe the evolution of SR perceptions over time. Finally, the relative merits and drawbacks of passive, compared to active, learning of SR warrant greater attention in the literature.

Author Contributions: Conceptualization: F.C.-P. and M.C.R.-R., methodology: F.C.-P. and A.L.-G.; formal analysis: A.M. and A.L.-G.; writing-original draft preparation and writing-review and editing: F.C.-P., M.C.R.-R., A.M., A.L.-G., M.C.d.l.F., E.C.R. and M.C.-R.; project administration: F.C.-P. All authors have read and agreed to the published version of the manuscript. 
Funding: This research was funded by Teaching Innovation Project entitled “Active learning of Social Responsibility within the Management Accounting subjects", funded by the I2D-UJA 2016-2018 Plan of the University of Jaén.

Conflicts of Interest: The authors declare no conflict of interest.

\section{Appendix A}

Table A1. Studies on university students' perceptions of SR.

\begin{tabular}{|c|c|c|c|c|}
\hline Authors & Sample/Scope & $\begin{array}{l}\text { Methodology/ } \\
\text { Approach }\end{array}$ & Objectives & Conclusions \\
\hline $\begin{array}{l}\text { Rodriguez et } \\
\text { al. [10] }\end{array}$ & $\begin{array}{l}1318 \text { students, } 104 \text { teachers, } \\
118 \text { administrative staff, and } \\
29 \text { academic managers from } \\
4 \text { universities in Rio Grande } \\
\text { Norte (Brazil) }\end{array}$ & Questionnaire & $\begin{array}{l}\text { To study perceptions of } \\
\text { facets of SR held by } \\
\text { students, teachers, } \\
\text { administrative staff, and } \\
\text { academic managers }\end{array}$ & $\begin{array}{l}\text { All three stakeholder groups } \\
\text { positively assess SR in the university } \\
\text { environment, and are committed to } \\
\text { improving the participation of these } \\
\text { stakeholder groups in actions focused } \\
\text { on achieving SR. For students, the } \\
\text { main concern is the environment, } \\
\text { followed by issues such as } \\
\text { community development, consumer } \\
\text { issues, and labor and legal practices }\end{array}$ \\
\hline $\begin{array}{l}\text { Galvao et al. } \\
\text { [28] }\end{array}$ & $\begin{array}{l}317 \text { students pursuing } \\
\text { undergraduate degrees in } \\
\text { Life Sciences, Engineering } \\
\text { Sciences, and Economic and } \\
\text { Business Sciences at the } \\
\text { University of Tras-os-Montes } \\
\text { and Alto Douro (Portugal) }\end{array}$ & Questionnaire & $\begin{array}{l}\text { To study the factors that } \\
\text { influence the orientation } \\
\text { of students towards SR }\end{array}$ & $\begin{array}{l}\text { Gender, religion, and volunteerism } \\
\text { are the most influential variables that } \\
\text { affect SR orientation. In fact, women, } \\
\text { religious students, and student } \\
\text { volunteers show a stronger ethical } \\
\text { and SR orientation }\end{array}$ \\
\hline $\begin{array}{l}\text { Ruiz-Palomino } \\
\text { et al. [11] }\end{array}$ & $\begin{array}{l}97 \text { university students } \\
\text { enrolled in a non-university } \\
\text { SR course at a Spanish state } \\
\text { university }\end{array}$ & Questionnaire & $\begin{array}{l}\text { To analyze changes in } \\
\text { students' SR perceptions } \\
\text { once they have taken an } \\
\text { SR course }\end{array}$ & $\begin{array}{l}\text { They conclude that taking an SR } \\
\text { training course improves students' } \\
\text { ethical decision-making. Furthermore, } \\
\text { the impact is greater on female } \\
\text { students than on male students }\end{array}$ \\
\hline $\begin{array}{l}\text { Tormo-Carbó } \\
\text { et al. [20] }\end{array}$ & $\begin{array}{l}307 \text { management students at } \\
\text { the University of Science } \\
\text { and Technology of Krakow } \\
\text { (Poland) }\end{array}$ & Questionnaire & $\begin{array}{l}\text { To analyze ethical } \\
\text { perceptions as part of SR, } \\
\text { detecting differences in } \\
\text { such perceptions } \\
\text { according to gender, age, } \\
\text { work experience, and } \\
\text { ethics courses completed }\end{array}$ & $\begin{array}{l}\text { They detected significant differences } \\
\text { in the ethical perceptions of the } \\
\text { students in the sample with respect to } \\
\text { gender and age with women and } \\
\text { older students being more inclined } \\
\text { towards ethical issues. Completion of } \\
\text { an ethics course and professional } \\
\text { experience were not significant } \\
\text { variables }\end{array}$ \\
\hline $\begin{array}{l}\text { Larrán et al. } \\
\text { [29] }\end{array}$ & $\begin{array}{l}319 \text { students at the } \\
\text { University of Cadiz (Spain) }\end{array}$ & $\begin{array}{l}\text { Questionnaire and } \\
\text { hypothesis testing }\end{array}$ & $\begin{array}{l}\text { To study the perceptions } \\
\text { of business students } \\
\text { towards SR and analyze } \\
\text { the role of cultural, } \\
\text { socio-economic, and } \\
\text { legal factors in } \\
\text { explaining the results }\end{array}$ & $\begin{array}{l}\text { Gender, grade, and course are the } \\
\text { variables most associated with } \\
\text { students' perceptions of SR. There is a } \\
\text { high level of concern for the social } \\
\text { and environmental dimension of SR. } \\
\text { Students in the business and } \\
\text { accounting degree are the most aware } \\
\text { of social and environmental aspects }\end{array}$ \\
\hline $\begin{array}{l}\text { Deer and } \\
\text { Zarestky [16] }\end{array}$ & $\begin{array}{l}14 \text { students enrolled in an } \\
\text { undergraduate SR course at } \\
\text { a top U.S. university }\end{array}$ & $\begin{array}{l}\text { Thematic and } \\
\text { narrative analysis }\end{array}$ & $\begin{array}{l}\text { To study the evolution of } \\
\text { students' perspectives } \\
\text { when taking an SR } \\
\text { course }\end{array}$ & $\begin{array}{l}\text { SR concepts motivated students to } \\
\text { solve SR-related problems and gave } \\
\text { them confidence in their SR skills. } \\
\text { Students need to strengthen their } \\
\text { critical thinking on SR by increasing } \\
\text { their social awareness. They highlight } \\
\text { the gap in SR training }\end{array}$ \\
\hline $\begin{array}{l}\text { Martínez- } \\
\text { Usarralde et } \\
\text { al. [24] }\end{array}$ & $\begin{array}{l}206 \text { students taking a degree } \\
\text { in Social Education at the } \\
\text { University of Valencia } \\
\text { (Spain) }\end{array}$ & $\begin{array}{l}\text { Questionnaire, } \\
\text { qualitative study } \\
\text { with students, data } \\
\text { triangulation }\end{array}$ & $\begin{array}{l}\text { To analyze the state of } \\
\text { the art of SR and } \\
\text { sustainable development } \\
\text { at the University of } \\
\text { Valencia }\end{array}$ & $\begin{array}{l}\text { Students consider that the university } \\
\text { provides them with tools to be } \\
\text { socially responsible and is concerned } \\
\text { about social problems although issues } \\
\text { with value formation were identified }\end{array}$ \\
\hline $\begin{array}{l}\text { Pätäri et al. } \\
\text { [30] }\end{array}$ & $\begin{array}{l}\text { Students at Lappeenranta } \\
\text { University of Technology, } \\
\text { University of Turku and } \\
\text { University of Helsinki in } \\
\text { Finland in 2015, Deusto } \\
\text { University in Spain during } \\
\text { 2015-2016, and a public } \\
\text { forum of university students } \\
\text { in Kong }\end{array}$ & $\begin{array}{l}\text { Online } \\
\text { questionnaires and } \\
\text { hypothesis testing }\end{array}$ & $\begin{array}{l}\text { To analyze the } \\
\text { perceptions of students } \\
\text { in about SR and the } \\
\text { future of the forest } \\
\text { industry }\end{array}$ & $\begin{array}{l}\text { They conclude that nationality, } \\
\text { gender, age, and field of study } \\
\text { positively influence students' } \\
\text { perceptions of sustainability and } \\
\text { social and environmental } \\
\text { performance. Nationality and field of } \\
\text { study are related to students' } \\
\text { perceptions of SR }\end{array}$ \\
\hline
\end{tabular}


Table A1. Cont.

\begin{tabular}{|c|c|c|c|c|}
\hline Authors & Sample/Scope & $\begin{array}{l}\text { Methodology/ } \\
\text { Approach }\end{array}$ & Objectives & Conclusions \\
\hline $\begin{array}{l}\text { Claver et al. } \\
\text { [41] }\end{array}$ & $\begin{array}{l}288 \text { students at the } \\
\text { University of Alicante in } \\
2012 \text { and } 2016 \text { (Spain) }\end{array}$ & $\begin{array}{l}\text { Exploratory factor } \\
\text { analysis }\end{array}$ & $\begin{array}{l}\text { To analyze the } \\
\text { cost-benefit ratio of SR }\end{array}$ & $\begin{array}{l}\text { Evolution of interest in ethical and SR } \\
\text { issues ( } 2012 \text { vs. 2016). The strategic } \\
\text { value of ethics and SR is confirmed }\end{array}$ \\
\hline $\begin{array}{l}\text { Costa et al. } \\
{[31]}\end{array}$ & $\begin{array}{l}117 \text { students in the first year } \\
\text { of the undergraduate course } \\
\text { in financial accounting, the } \\
\text { third year of the } \\
\text { undergraduate course in } \\
\text { ethics and deontology, and } \\
\text { the first year of the Master's } \\
\text { degree in advanced } \\
\text { accounting at the Higher } \\
\text { Institute of Accounting and } \\
\text { Administration (Portugal) }\end{array}$ & Questionnaire & $\begin{array}{l}\text { To analyze whether } \\
\text { gender, age, work } \\
\text { experience, and the } \\
\text { completion of an ethics } \\
\text { course as part of SR } \\
\text { influence the ethical } \\
\text { perceptions of these } \\
\text { students and study } \\
\text { individual factors that } \\
\text { may affect ethics in } \\
\text { decision-making }\end{array}$ & $\begin{array}{l}\text { Gender, age, work experience, and } \\
\text { attendance at an ethics course } \\
\text { influence students' ethical } \\
\text { perceptions. Specifically, gender } \\
\text { affects initiative/entrepreneurship, } \\
\text { obedience and responsibility, age } \\
\text { affects integrity, work experience } \\
\text { affects obedience, and attendance at } \\
\text { an ethics course affects independence, } \\
\text { all treated as individual factors }\end{array}$ \\
\hline $\begin{array}{l}\text { Alonso-Almeida } \\
\text { et al. [14] }\end{array}$ & $\begin{array}{l}535 \text { business students at the } \\
\text { Autonomous University of } \\
\text { Madrid (Spain) }\end{array}$ & $\begin{array}{l}\text { Questionnaire and } \\
\text { factor analysis }\end{array}$ & $\begin{array}{l}\text { To analyze the } \\
\text { perceptions of students } \\
\text { who are not familiar } \\
\text { with SR }\end{array}$ & $\begin{array}{l}\text { Gender influences the perception of } \\
\text { SR. The role of Stakeholder Theory is } \\
\text { assessed, i.e., a relation with } \\
\text { stakeholders and a list of attributes } \\
\text { for the responsible company is } \\
\text { provided that differs from previous } \\
\text { work. The first position for the need } \\
\text { to attend to customers and the } \\
\text { eleventh position for environmental } \\
\text { management stand out }\end{array}$ \\
\hline $\begin{array}{l}\text { Whitley and } \\
\text { Yoder [36] }\end{array}$ & $\begin{array}{l}1240 \text { students at Michigan } \\
\text { State University (USA) }\end{array}$ & Survey & $\begin{array}{l}\text { To measure the impact of } \\
\text { curricular, } \\
\text { extracurricular, civic } \\
\text { engagement, and } \\
\text { community participation } \\
\text { on learning, attitudes, } \\
\text { and behavior related to } \\
\text { political engagement and } \\
\text { SR }\end{array}$ & $\begin{array}{l}\text { All three experiences are positively } \\
\text { related to attitudes and behaviors of } \\
\text { political commitment and SR. } \\
\text { Extracurricular civic engagement has } \\
\text { a greater impact on learning attitudes } \\
\text { related to SR }\end{array}$ \\
\hline $\begin{array}{l}\text { Martí et al. } \\
\text { [39] }\end{array}$ & $\begin{array}{l}860 \text { students from public } \\
\text { universities (Spain, Chile, } \\
\text { Colombia, and Peru) }\end{array}$ & $\begin{array}{l}\text { Structural equation } \\
\text { model }\end{array}$ & $\begin{array}{l}\text { To analyze how } \\
\text { university education } \\
\text { influences the } \\
\text { acquisition of } \\
\text { responsible behavior by } \\
\text { studying the } \\
\text { intentionality and } \\
\text { frequency of such } \\
\text { behavior }\end{array}$ & $\begin{array}{l}\text { Students exhibit socially responsible } \\
\text { behavior quite often. With respect to } \\
\text { frequency, the variables that influence } \\
\text { the self-attribution of socially } \\
\text { responsible behavior are the value of } \\
\text { conservation and openness to change } \\
\text { and respect for empathy. Students' } \\
\text { intentionality to be socially } \\
\text { responsible is influenced by the value } \\
\text { of conservation and by } \\
\text { self-transcendence }\end{array}$ \\
\hline
\end{tabular}


Table A1. Cont.

\begin{tabular}{|c|c|c|c|c|}
\hline Authors & Sample/Scope & $\begin{array}{l}\text { Methodology/ } \\
\text { Approach }\end{array}$ & Objectives & Conclusions \\
\hline Rus et al. [27] & $\begin{array}{l}536 \text { members from } 2 \text { public } \\
\text { universities (Romania) }\end{array}$ & Regression analysis & $\begin{array}{l}\text { To study the relationship } \\
\text { between university } \\
\text { members' perceptions of } \\
\text { the learning organization } \\
\text { and SR, distinguishing } \\
\text { three groups: students, } \\
\text { internal staff, and } \\
\text { leadership staff }\end{array}$ & $\begin{array}{l}\text { The seven dimensions of the learning } \\
\text { organization are related to SR. } \\
\text { The perceptions of internal groups } \\
\text { and students about the learning } \\
\text { organization have a greater } \\
\text { relationship with SR while leadership } \\
\text { staff showed a weaker relationship } \\
\text { between learning organization and SR }\end{array}$ \\
\hline $\begin{array}{l}\text { Vázquez et al. } \\
\text { [25] }\end{array}$ & $\begin{array}{l}400 \text { students at the } \\
\text { University of León (Spain) }\end{array}$ & $\begin{array}{l}\text { Questionnaire and } \\
\text { structural equation } \\
\text { models }\end{array}$ & $\begin{array}{l}\text { To analyze the factors } \\
\text { that define students' SR } \\
\text { perceptions }\end{array}$ & $\begin{array}{l}\text { Students consider that internal } \\
\text { management affects their perception } \\
\text { of SR. They highlight the need to } \\
\text { improve participation in SR actions } \\
\text { and university training in SR }\end{array}$ \\
\hline $\begin{array}{l}\text { Vázquez et al. } \\
\text { [19] }\end{array}$ & $\begin{array}{l}200 \text { final year students of } \\
\text { Economics and Business at } \\
\text { the Catholic University of } \\
\text { Uruguay }\end{array}$ & Questionnaire & $\begin{array}{l}\text { To analyze students' } \\
\text { perception of SR and } \\
\text { their expectations of } \\
\text { current SR education } \\
\text { and future demands for } \\
\text { SR education }\end{array}$ & $\begin{array}{l}\text { Great demand for education in SR, } \\
\text { especially content referring to } \\
\text { relations with employees, consumers, } \\
\text { and respect for the environment. } \\
\text { They conclude that higher education } \\
\text { influences students' concept of SR }\end{array}$ \\
\hline $\begin{array}{l}\text { Díaz and } \\
\text { Facal [35] }\end{array}$ & $\begin{array}{l}95 \text { students from the } \\
\text { Business School at the } \\
\text { Business University in } \\
\text { Montevideo (Uruguay) }\end{array}$ & Questionnaire & $\begin{array}{l}\text { To study the perceptions } \\
\text { of third- and fourth-year } \\
\text { students of BAM, } \\
\text { Marketing, Foreign } \\
\text { Trade, and Public } \\
\text { Accounting degrees of } \\
\text { the Business University } \\
\text { on SR }\end{array}$ & $\begin{array}{l}\text { Most of the students surveyed have } \\
\text { knowledge about SR, although it has } \\
\text { not been covered during their } \\
\text { university studies, but in } \\
\text { non-regulated courses }\end{array}$ \\
\hline $\begin{array}{l}\text { Fernández } \\
\text { Chulián [18] }\end{array}$ & $\begin{array}{l}20 \text { students studying for a } \\
\text { degree in business } \\
\text { administration and } \\
\text { management at Pablo de } \\
\text { Olavide University in Seville } \\
\text { (Spain) }\end{array}$ & $\begin{array}{l}\text { Questionnaire and } \\
\text { analysis of } \\
\text { students' discourse } \\
\text { before and after the } \\
\text { inclusion of the } \\
\text { subject }\end{array}$ & $\begin{array}{l}\text { To study the inclusion of } \\
\text { a subject related to SR } \\
\text { within the accounting } \\
\text { field (sustainability } \\
\text { accounting) }\end{array}$ & $\begin{array}{l}\text { Students showed changes in } \\
\text { discourse before and after taking the } \\
\text { accounting for sustainability course. } \\
\text { This will allow students to broaden } \\
\text { their view of business accounting and } \\
\text { relate it to sustainability issues }\end{array}$ \\
\hline
\end{tabular}


Table A1. Cont.

\begin{tabular}{|c|c|c|c|c|}
\hline Authors & Sample/Scope & $\begin{array}{l}\text { Methodology/ } \\
\text { Approach }\end{array}$ & Objectives & Conclusions \\
\hline $\begin{array}{l}\text { López-Navarro } \\
\text { et al. [33] }\end{array}$ & $\begin{array}{l}174 \text { students of Business } \\
\text { Administration and } \\
\text { Management in the first and } \\
\text { fourth year at Jaume I } \\
\text { University (Spain) }\end{array}$ & Questionnaire & $\begin{array}{l}\text { To analyze students' } \\
\text { attitudes towards SR }\end{array}$ & $\begin{array}{l}\text { Students prioritize their opinion on } \\
\text { SR, highlight differences between } \\
\text { current and desired ethical issues } \\
\text { because they do not receive the } \\
\text { desired SR training, and appreciate } \\
\text { differences in terms of gender, with } \\
\text { women placing more value on ethical } \\
\text { issues. First-year students placed a } \\
\text { higher value on ethical issues than } \\
\text { final-year students, who placed a } \\
\text { higher value on employee relations }\end{array}$ \\
\hline $\begin{array}{l}\text { Brunton and } \\
\text { Eweje [61] }\end{array}$ & $\begin{array}{l}536 \text { students from a business } \\
\text { school (New Zealand) }\end{array}$ & Questionnaire & $\begin{array}{l}\text { To analyze the influence } \\
\text { of culture on ethical } \\
\text { perceptions as part of SR }\end{array}$ & $\begin{array}{l}\text { Cultural differences affect the ethical } \\
\text { perceptions of the students in the } \\
\text { sample, with European students } \\
\text { standing out as the least aware of } \\
\text { ethical and SR issues compared to } \\
\text { Chinese students who were the most } \\
\text { aware }\end{array}$ \\
\hline $\begin{array}{l}\text { Eweje and } \\
\text { Brunton [40] }\end{array}$ & $\begin{array}{l}655 \text { undergraduate and } \\
\text { postgraduate business } \\
\text { students (New Zealand) }\end{array}$ & Questionnaire & $\begin{array}{l}\text { To analyze whether } \\
\text { gender, age, and work } \\
\text { experience influence the } \\
\text { ethical perceptions of } \\
\text { students, as part of SR }\end{array}$ & $\begin{array}{l}\text { They conclude that gender influences } \\
\text { ethical perceptions, highlighting } \\
\text { women with greater awareness of } \\
\text { ethics and SR. With regard to age, } \\
\text { they consider that it is not a factor } \\
\text { that significantly affects the ethical } \\
\text { and SR perceptions of the students in } \\
\text { the sample, while work experience } \\
\text { does have a positive influence on this } \\
\text { perception }\end{array}$ \\
\hline
\end{tabular}
perception

Ideology centered on ethical values affects the responsible behavior of students in the sample. In particular, idealism and relativism affect

Kolodinsky et 298 undergraduate students al. [12] at a university in the

Online Southeast USA
Online
questionnaires

To analyze factors that may influence students' attitudes to SR

behavior positively and negatively, respectively. They do not find a significant relationship between spirituality and responsible behavior. Nationality and gender do not significantly affect the ethical behavior of the students

There are few differences in student behavior according to gender, although women appear to be slightly more aware of social values than men. Psychosocial variables such as educational level and nationality are

To analyze the influen of students' personal characteristics on sustainable development and SR

predictors of responsible behavior in

the students in the sample. The

values of an environmentally conscious leader can influence the pro-environmental behavior of followers

American and Indian students attach greater importance to SR issues than do Chinese students. American students place more emphasis on economic issues while Indian

317 top-level business

Wong et al. students from higher

[62] education institutions in USA, China, and India
Questionnaire

To compare business students' perceptions of $\mathrm{SR}$ in American, Indian, and Chinese universities students emphasize philanthropy.

They find no significant differences in the perception of ethical issues between the three groups. Chinese respondents emphasize economic issues over SR issues. SR practices are similar across the three cultures 
Table A1. Cont.

\begin{tabular}{|c|c|c|c|c|}
\hline Authors & Sample/Scope & $\begin{array}{l}\text { Methodology/ } \\
\text { Approach }\end{array}$ & Objectives & Conclusions \\
\hline $\begin{array}{l}\text { Lämsa et al. } \\
\text { [13] }\end{array}$ & $\begin{array}{l}217 \text { business students from } \\
\text { two Finnish universities } \\
\text { between } 2003 \text { and } 2006\end{array}$ & Questionnaire & $\begin{array}{l}\text { To analyze the effect of } \\
\text { entrepreneurship } \\
\text { education on students' } \\
\text { attitudes and behaviors } \\
\text { on SR issues }\end{array}$ & $\begin{array}{l}\text { Females are more aware of ethical, } \\
\text { social, and environmental issues than } \\
\text { males, at the beginning and end of } \\
\text { their studies. The level and context of } \\
\text { education also has a positive } \\
\text { influence on the perceptions of } \\
\text { aspects related to SR, so that the } \\
\text { higher the socio-cultural level, the } \\
\text { greater the awareness of SR }\end{array}$ \\
\hline $\begin{array}{l}\text { Ibrahim et al. } \\
\text { [38] }\end{array}$ & $\begin{array}{l}272 \text { accountants and } 374 \\
\text { accounting students from } 6 \\
\text { universities accredited by } \\
\text { the Association to Advance } \\
\text { Collegiate Schools of } \\
\text { Business (USA) }\end{array}$ & Questionnaire & $\begin{array}{l}\text { To study similarities and } \\
\text { differences among } \\
\text { students regarding their } \\
\text { SR behaviors }\end{array}$ & $\begin{array}{l}\text { There is greater concern about } \mathrm{SR} \text { and } \\
\text { ethical issues than about economic } \\
\text { issues }\end{array}$ \\
\hline Elias [26] & $\begin{array}{l}324 \text { undergraduate and } \\
\text { graduate students in } \\
\text { business studies at three } \\
\text { universities in the } \\
\text { Southwest, Southeast, and } \\
\text { Mountain regions of the } \\
\text { USA }\end{array}$ & Questionnaire & $\begin{array}{l}\text { To analyze students' } \\
\text { perceptions of the } \\
\text { sample universities } \\
\text { towards SR after } \\
\text { university bankruptcies }\end{array}$ & $\begin{array}{l}\text { They believe that SR is more } \\
\text { important for the long-term } \\
\text { profitability and success of } \\
\text { universities and less relevant for their } \\
\text { short-term success due to advertising } \\
\text { scandals. Male, older, and more } \\
\text { experienced students are less likely to } \\
\text { change their perceptions of SR } \\
\text { compared to younger and less } \\
\text { experienced female students. } \\
\text { Students of economics, finance, and } \\
\text { information management are more } \\
\text { aware of SR than students of } \\
\text { accounting, administration, and } \\
\text { marketing }\end{array}$ \\
\hline Peppas [21] & $\begin{array}{l}309 \text { students enrolled in the } \\
\text { business school of a private } \\
\text { university in the Southeast } \\
\text { USA during the 1998-1999 } \\
\text { academic year (Asian and } \\
\text { American internationals) }\end{array}$ & Case Study & $\begin{array}{l}\text { To study changes in } \\
\text { students' behavior after } \\
\text { taking courses with an } \\
\text { ethical content }\end{array}$ & $\begin{array}{l}\text { Asian international students showed } \\
\text { no difference after taking this } \\
\text { ethics-focused training. American } \\
\text { students showed differences in their } \\
\text { ethics-related behaviors }\end{array}$ \\
\hline $\begin{array}{l}\text { Kraft and } \\
\text { Singhapakdi } \\
\text { [63] }\end{array}$ & $\begin{array}{l}182 \text { final year students of } \\
\text { business degrees and MBAs } \\
\text { from universities in the } \\
\text { Midwest, Mid-Atlantic. and } \\
\text { South (USA) }\end{array}$ & Questionnaire & $\begin{array}{l}\text { To analyze the relative } \\
\text { importance of SR criteria } \\
\text { to determine the } \\
\text { effectiveness of the } \\
\text { sample universities }\end{array}$ & $\begin{array}{l}\text { The SR criteria are the least important } \\
\text { in determining the effectiveness of the } \\
\text { universities studied. MBA students } \\
\text { scored higher on SR criteria than } \\
\text { undergraduates, and female students } \\
\text { were more aware of SR issues. Work } \\
\text { experience, nationality, and age of } \\
\text { students are not significantly } \\
\text { correlated with SR criteria. }\end{array}$ \\
\hline
\end{tabular}




\section{Appendix B}

Table A2. Studies on the SDGs and universities.

\begin{tabular}{|c|c|c|c|c|}
\hline Authors & Sample/Scope & $\begin{array}{l}\text { Methodology/ } \\
\text { Approach }\end{array}$ & Objectives & Conclusions \\
\hline $\begin{array}{l}\text { Isenmann et } \\
\text { al. [64] }\end{array}$ & $\begin{array}{l}\text { State University of Science } \\
\text { and Private University of } \\
\text { Science of Munich } \\
\text { (Germany) }\end{array}$ & $\begin{array}{l}\text { Case study: } \\
\text { Morphological box } \\
\text { for education for } \\
\text { sustainable } \\
\text { development }\end{array}$ & $\begin{array}{l}\text { To study the } \\
\text { implementation of } \\
\text { education for sustainable } \\
\text { development at } \\
\text { university level }\end{array}$ & $\begin{array}{l}\text { The Morphological box is useful for } \\
\text { analyzing the current state of } \\
\text { implementation of education for } \\
\text { sustainable development in faculties } \\
\text { and departments, for adjusting its } \\
\text { evolution throughout the course, and } \\
\text { for obtaining a university-wide } \\
\text { overview of education for sustainable } \\
\text { development, which contributes to } \\
\text { SDG implementation in universities. } \\
\text { It includes the identification and } \\
\text { development of new profiles of } \\
\text { education for sustainable } \\
\text { development as well as the } \\
\text { communication and evaluation of } \\
\text { existing profiles on sustainable } \\
\text { development }\end{array}$ \\
\hline $\begin{array}{l}\text { Avelar et al. } \\
{[45]}\end{array}$ & $\begin{array}{l}193 \text { articles from the Social } \\
\text { Sciences Citation Index } \\
\text { (SSCI) and the Emerging } \\
\text { Sources Citation Index } \\
\text { (ESCI) available on Web of } \\
\text { Science from } 2015 \text { to } 2018\end{array}$ & $\begin{array}{l}\text { Bibliometric } \\
\text { analysis }\end{array}$ & $\begin{array}{l}\text { To conduct a systematic } \\
\text { review of the literature } \\
\text { on SDG-oriented } \\
\text { education }\end{array}$ & $\begin{array}{l}\text { SDGs are addressed at all levels of } \\
\text { education, and implementing these } \\
\text { SDGs will require education to be at } \\
\text { the center of the strategy. The } \\
\text { University of London has published } \\
\text { the most articles on SDGs. Achieving } \\
\text { quality education will involve raising } \\
\text { the awareness of educators, business } \\
\text { leaders, and governments in the } \\
\text { dissemination of information about } \\
\text { the SDGs. The increase in the number } \\
\text { of published articles focused on the } \\
\text { achievement of SDGs in higher } \\
\text { education in the period and } \\
\text { individual authorship are factors that } \\
\text { recognize the importance of } \\
\text { education in implementing the SDGs, } \\
\text { with the UK and US being the most } \\
\text { popular countries for disseminating } \\
\text { information on the SDGs }\end{array}$ \\
\hline $\begin{array}{l}\text { De la Rosa et } \\
\text { al. [51] }\end{array}$ & $\begin{array}{l}639 \text { students from Francisco } \\
\text { of Vitoria University (Spain) }\end{array}$ & $\begin{array}{l}\text { Empirical study } \\
\text { structured in } 4 \\
\text { dimensions and } 21 \\
\text { items }\end{array}$ & $\begin{array}{l}\text { To analyze the impact of } \\
\text { teaching SR and SDG } \\
\text { information on } \\
\text { university students }\end{array}$ & $\begin{array}{l}\text { It is verified that SR content improves } \\
\text { student commitment and contributes } \\
\text { to the achievement of SDG } 4.7\end{array}$ \\
\hline $\begin{array}{l}\text { Fleacă, et al. } \\
{[65]}\end{array}$ & - & $\begin{array}{l}\text { Case study } \\
\text { applying the } \\
\text { SIPOC method } \\
\text { (Supplier, Input, } \\
\text { Process, Output, } \\
\text { Customer) }\end{array}$ & $\begin{array}{l}\text { To analyze the capacity } \\
\text { of universities to } \\
\text { integrate the principles } \\
\text { and practices of } \\
\text { sustainable development } \\
\text { into university education }\end{array}$ & $\begin{array}{l}\text { They detect a lack of capacity in the } \\
\text { universities analyzed to integrate the } \\
\text { principles of sustainable development } \\
\text { into education and, consequently, the } \\
\text { difficulty of acting as an } \\
\text { entrepreneurial university. It will be } \\
\text { necessary to design, implement, } \\
\text { monitor, control, and report on the } \\
\text { efforts that universities make towards } \\
\text { the achievement of SDGs }\end{array}$ \\
\hline $\begin{array}{l}\text { Giler et al. } \\
\text { [52] }\end{array}$ & $\begin{array}{l}\text { Tsáchilas Higher } \\
\text { Technological Institute of } \\
\text { Santo Domingo de los } \\
\text { Tsáchilas (Ecuador) }\end{array}$ & Case Study & $\begin{array}{l}\text { To analyze SDG } \\
\text { implementation }\end{array}$ & $\begin{array}{l}\text { The inclusion of SDGs in the actions of } \\
\text { this higher education center is marked } \\
\text { by its relationship with stakeholders. } \\
\text { The activities developed by this } \\
\text { institute were designed to fulfill the } \\
\text { objective of SDG } 4\end{array}$ \\
\hline $\begin{array}{l}\text { Albareda-Tiana, } \\
\text { et al. [66] }\end{array}$ & $\begin{array}{l}23 \text { students of the Degree in } \\
\text { Primary Education of the } \\
\text { Faculty of Education of the } \\
\text { International University of } \\
\text { Catalonia (Spain) }\end{array}$ & Case Study & $\begin{array}{l}\text { To study the most } \\
\text { appropriate } \\
\text { methodologies for } \\
\text { developing sustainability } \\
\text { skills in higher education } \\
\text { and to analyze whether } \\
\text { the acquisition of } \\
\text { sustainability skills is } \\
\text { related to research }\end{array}$ & $\begin{array}{l}\text { Project-based learning is a suitable } \\
\text { methodology for developing } \\
\text { sustainability skills. } \\
\text { There is a positive correlation between } \\
\text { sustainability skills and research }\end{array}$ \\
\hline
\end{tabular}


Table A2. Cont.

\begin{tabular}{|c|c|c|c|c|}
\hline Authors & Sample/Scope & $\begin{array}{l}\text { Methodology/ } \\
\text { Approach }\end{array}$ & Objectives & Conclusions \\
\hline $\begin{array}{l}\text { Millán and } \\
\text { Pérez [48] }\end{array}$ & $\begin{array}{l}\text { University of Valencia and } \\
\text { Polytechnic University of } \\
\text { Valencia (Spain) }\end{array}$ & Case Study & $\begin{array}{l}\text { To study the } \\
\text { establishment of SDGs in } \\
\text { the sample universities }\end{array}$ & $\begin{array}{l}\text { The universities in the sample have } \\
\text { adapted in a practical way to the new } \\
\text { goals, policies, and plans of Agenda } \\
\text { 2030, although there is a need to } \\
\text { improve certain aspects such as } \\
\text { teacher training and the } \\
\text { dissemination of information about } \\
\text { Agenda } 2030 \text { and the SDGs }\end{array}$ \\
\hline $\begin{array}{l}\text { Annan-Diab } \\
\text { and Molinari } \\
{[50]}\end{array}$ & $\begin{array}{l}200 \text { final year MBA students } \\
\text { ( } 80 \text { from UK and } 120 \text { from } \\
\text { Russia) }\end{array}$ & Case Study & $\begin{array}{l}\text { To analyze the } \\
\text { importance of an } \\
\text { interdisciplinary } \\
\text { approach in education } \\
\text { for sustainable } \\
\text { development and SR }\end{array}$ & $\begin{array}{l}\text { They believe that studying a module } \\
\text { focused on sustainability and SR can } \\
\text { help students combine all their } \\
\text { knowledge and advance in } \\
\text { sustainable development. Improved } \\
\text { interdisciplinarity in education will } \\
\text { help meet the SDGs }\end{array}$ \\
\hline $\begin{array}{l}\text { De Menezes } \\
\text { and Minillo } \\
{[44]}\end{array}$ & $\begin{array}{l}\text { Federal University of } \\
\text { Paraíba of Brazil }\end{array}$ & Case Study & $\begin{array}{l}\text { To describe the } \\
\text { importance of the } \\
\text { university in the } \\
\text { development of } \\
\text { countries and in the } \\
\text { implementation of the } \\
\text { SDGs }\end{array}$ & $\begin{array}{l}\text { Training, research, and extension } \\
\text { activities cannot be separated, as they } \\
\text { facilitate the university's contribution } \\
\text { to sustainable development and } \\
\text { compliance with the SDGs }\end{array}$ \\
\hline $\begin{array}{l}\text { Kolb et al. } \\
{[46]}\end{array}$ & German Business School & Case Study & $\begin{array}{l}\text { To study the relationship } \\
\text { between SDGs and } \\
\text { education in the business } \\
\text { schools in the sample }\end{array}$ & $\begin{array}{l}\text { The educational level of leaders } \\
\text { influences the achievement of the } \\
\text { SDGs. Educational models should } \\
\text { educate leaders to promote the } \\
\text { achievement of the SDGs. }\end{array}$ \\
\hline $\begin{array}{l}\text { Weybrecht } \\
\text { [47] }\end{array}$ & - & Theoretical review & $\begin{array}{l}\text { To discuss how to } \\
\text { consider educating } \\
\text { future managers to be } \\
\text { socially responsible and } \\
\text { follow the SDGs }\end{array}$ & $\begin{array}{l}\text { Higher education of future business } \\
\text { leaders influences the implementation } \\
\text { of SDGs and the achievement of } \\
\text { sustainable development in society } \\
\text { and therefore higher education } \\
\text { should be enhanced }\end{array}$ \\
\hline
\end{tabular}

\section{References}

1. Lozano, R. Incorporation and institutionalization of SD into universities: Breaking through barriers to change. J. Clean. Prod. 2006, 14, 787-796. [CrossRef]

2. Armstrong, M.B.; Ketz, J.E.; Owsen, D. Ethics education in accounting: Moving toward ethical motivation and ethical behavior. J. Account. Educ. 2003, 21,1-16. [CrossRef]

3. Setó-Pamies, D.; Papaoikonomou, E. A Multi-level Perspective for the Integration of Ethics, Corporate Social Responsibility and Sustainability (ECSRS) in Management Education. J. Bus. Ethics 2016, 136, 523-538. [CrossRef]

4. Da Silva Junior, A.; De Oliveira Martins-Silva, P.; De Araújo Vasconcelos, K.C.; da Silva, V.C.; de Brito, S.L.M.S.; Rocha Monteiro, J.M. Sustainability and corporate social responsibility in the opinion of undergraduate students in management programs: Between the concrete and the abstract. J. Clean. Prod. 2019, 207, 600-617. [CrossRef]

5. Mcwilliams, A.; Siegel, D. Corporate Social Responsibility: A Theory of the Firm Perspective. Acad. Manag. Rev. 2001, 26, 117-127. [CrossRef]

6. Correa, J.A. La profesión contable y los objetivos de desarrollo sostenible (ODS). Contaduría Univ. Antioq. 2019, 74, 9-11. 
7. Soderstrom, K.M.; Soderstrom, N.S.; Stewart, C.R. Sustainability/csr research in management accounting: A review of the literature. In Advances in Management Accounting; Emerald Group Publishing Ltd.: Bingley, UK, 2017; Volume 28, pp. 59-85.

8. CERSE. Corporate Social Responsibility, Sustainable Development, and the Education and Training System. Available online: http://www.mitramiss.gob.es/ficheros/rse/documentos/cerse/4_RSE_y_Educacion.pdf (accessed on 15 May 2020).

9. Parkes, C.; Buono, A.F.; Howaidy, G. The Principles for responsible management education (PRME): The first decade—What has been achieved? The next decade—Responsible management Education's challenge for the Sustainable Development Goals (SDGs). Int. J. Manag. Educ. 2017, 15, 61-65. [CrossRef]

10. Rodríguez, J.C.; Stradiotto, E.; Binotto, E.; Nepomuceno, L.H. University social responsibility: Perceptions and advantages. Soc. Responsib. J. 2020. [CrossRef]

11. Ruiz-Palomino, P.; Martínez-Cañas, R.; Jiménez-Estévez, P. Are corporate social responsibility courses effective? A longitudinal and gender-based analysis in undergraduate students. Sustainability 2019, 11, 6033. [CrossRef]

12. Kolodinsky, R.W.; Madden, T.M.; Zisk, D.S.; Henkel, E.T. Attitudes about corporate social responsibility: Business student predictors. J. Bus. Ethics 2010, 91, 167-181. [CrossRef]

13. Lämsä, A.M.; Vehkaperä, M.; Puttonen, T.; Pesonen, H.L. Effect of business education on women and men students' attitudes on corporate responsibility in society. J. Bus. Ethics 2008, 82, 45-58. [CrossRef]

14. Alonso-Almeida, M.D.M.; De Navarrete, F.C.F.; Rodriguez-Pomeda, J. Corporate social responsibility perception in business students as future managers: A multifactorial analysis. Bus. Ethics 2015, 24, 1-17. [CrossRef]

15. McDonald, G.M. A case example: Integrating ethics into the academic business curriculum. J. Bus. Ethics 2004, 54, 371-384. [CrossRef]

16. Deer, S.; Zarestky, J. Balancing Profit and People: Corporate Social Responsibility in Business Education. J. Manag. Educ. 2017, 41, 727-749. [CrossRef]

17. Luthar, H.K.; Karri, R. Exposure to ethics education and the perception of linkage between organizational ethical behavior and business outcomes. J. Bus. Ethics 2005, 61, 353-368. [CrossRef]

18. Fernández Chulián, M. Constructing new accountants: The role of sustainability education. Rev. Contab. Account. Rev. 2011, 14, 245-265.

19. Vázquez, J.L.; Lanero, A.; Licadro, O. Corporate Social Responsibility and higher education: Uruguay university students' perceptions. Econ. Sociol. 2013, 6, 145-157. [CrossRef]

20. Tormo-Carbó, G.; Oltra, V.; Klimkiewicz, K.; Seguí-Mas, E. "Don't try to teach me, I got nothing to learn": Management students' perceptions of business ethics teaching. Bus. Ethics 2019, 29, 506-528. [CrossRef]

21. Peppas, S. Attitudes towards business ethics: Where East doesn't meet West. Cross Cult. Manag. Int. J. 2002, 9, 42-59. [CrossRef]

22. Sánchez-Hernández, M.I.; Mainardes, E.W. University social responsibility: A student base analysis in Brazil. Int. Rev. Public Nonprofit Mark. 2016, 13, 151-169. [CrossRef]

23. Vázquez, J.L.; Lanero, A.; Alza, C.A. Students' experiences of university social responsibility and perceptions of satisfaction and quality of service. Rev. Contemp. Entrep. Bus. Econ. Issues 2015, 28, 25-39.

24. Martínez-Usarralde, M.J.; Lloret-Catalá, C.; Mas-Gil, S. Responsabilidad Social Universitaria (RS: Principios para una Universidad Sostenible, Cooperativa y Democrática desde el Diagnóstico Participativo de su Alumnado. Arch. Analíticos Políticas Educ. 2017, 25, 1-25.

25. Vázquez, J.L.; Aza, C.L.; Lanero, A. Are students aware of university social responsibility? Some insights from a survey in a Spanish university. Int. Rev. Public Nonprofit Mark. 2014, 11, 195-208. [CrossRef]

26. Elias, R.Z. An Examination of Business Students' Perception of Corporate Social Responsibilities Before and After Bankruptcies. J. Bus. Ethics 2004, 52, 267-281. [CrossRef]

27. Rus, C.L.; Chirică, S.; Raţiu, L.; Băban, A. Learning Organization and Social Responsibility in Romanian Higher Education Institutions. Procedia Soc. Behav. Sci. 2014, 142, 146-153. [CrossRef]

28. Galvão, A.; Mendes, L.; Marques, C.; Mascarenhas, C. Factors influencing students' corporate social responsibility orientation in higher education. J. Clean. Prod. 2019, 215, 290-304. [CrossRef]

29. Larrán, M.; Andrades, F.J.; Herrera, J. An examination of attitudes and perceptions of Spanish business and accounting students toward corporate social responsibility and sustainability themes. Rev. Contab. Account. Rev. 2018, 21, 196-205. [CrossRef] 
30. Pätäri, S.; Arminen, H.; Albareda, L.; Puumalainen, K.; Toppinen, A. Student values and perceptions of corporate social responsibility in the forest industry on the road to a bioeconomy. For. Policy Econ. 2017, 85, 201-215. [CrossRef]

31. Costa, A.J.; Pinheiro, M.M.; Ribeiro, M.S. Ethical perceptions of accounting students in a Portuguese university: The influence of individual factors and personal traits. Account. Educ. 2016, 25, 327-348. [CrossRef]

32. Ruiz-Corbella, M.; Ruiz, M.J.B.C. La responsabilidad social en la universidad espanola. Teoría de la Educación. Rev. Interuniv. 2016, 28, 159-188. [CrossRef]

33. López Navarro, M.Á.; Segarra Ciprés, M. Actitudes de los estudiantes de administración de empresas hacia la responsabilidad social corporativa y la ética empresarial. Rev. Complut. Educ. 2011, 22, 235-248. [CrossRef]

34. Andrades, F.J.; Larrán, M.; Murial, M.J. Analyzing the incorporation of sustainability issues in university curricula: A case study of a Spanish public university. Int. J. Sustain. Dev. World Ecol. 2018, 25, 242-254.

35. Díaz, M.; Facal, S. Percepciones de los estudiantes de la Facultad de Ciencias Empresariales sobre la Responsabilidad Social Universitaria (Montevideo-Uruguay). Investig. Desarro. 2011, 19, 340-365.

36. Whitley, C.T.; Yoder, S.D. Developing social responsibility and political engagement: Assessing the aggregate impacts of university civic engagement on associated attitudes and behaviors. Educ. Citizsh. Soc. Justice 2015, 10, 217-233. [CrossRef]

37. Crespo, B.; Míguez-álvarez, C.; Arce, M.E.; Cuevas, M.; Míguez, J.L. The sustainable development goals: An experience on higher education. Sustainability 2017, 9, 1353. [CrossRef]

38. Ibrahim, N.A.; Angelidis, J.P.; Howard, D.P. Corporate social responsibility: A comparative analysis of perceptions of practicing accountants and accounting students. J. Bus. Ethics 2006, 66, 157-167. [CrossRef]

39. Martí Noguera, J.J.; Martí-Vilar, M.; Almerich, G. Responsabilidad social universitaria: Influencia de valores y empatía en la autoatribución de comportamientos socialmente responsables. Rev. Latinoam. Psicol. 2014, 46, 160-168. [CrossRef]

40. Eweje, G.; Brunton, M. Ethical perceptions of business students in a New Zealand university: Do gender, age and work experience matter? Bus. Ethics 2010, 19, 95-111. [CrossRef]

41. Claver-Cortes, E.; Marco-Lajara, B.; García-Lillo, F.; Quer-Ramón, D.; Manresa-Marhuenda, E.; Molina-Manchón, H.; Rienda-García, L.; Úbeda-García, M.; Zaragoza-Sáez, P.; Andreu-Guerrero, R. Percepción de los Estudiantes del Grado de ADE Sobre la Ética y la Responsabilidad Social Corporativa y su Influencia en la Ventaja Competitiva de las Empresas. Available online: https://aprendeenlinea.udea.edu.co/ revistas/index.php/cont/index (accessed on 15 May 2020).

42. SDSN Australia/Pacific Getting Started with the SDGs in Universities: A Guide for Universities, Higher Education Institutions, and the Academic Sector. Available online: http://ap-unsdsn.org/wp-content/uploads/ University-SDG-Guide_web.pdf (accessed on 12 May 2020).

43. Cosme Casulo, J. Los Objetivos de Desarrollo Sostenible y la Academia. Medisan 2018, 22, 838-848.

44. De Menezes, H.Z.; Minillo, X.K. Research and extension as a University contribution in the implementation of objectives of sustainable development goals (SDGs) in Brazil. J. Glob. Stud. 2017, 18, 1-16. [CrossRef]

45. Avelar, A.B.A.; Da Silva-Oliveira, K.D.; da Silva Pereira, R. Education for advancing the implementation of the Sustainable Development Goals: A systematic approach. Int. J. Manag. Educ. 2019, 17. [CrossRef]

46. Kolb, M.; Fröhlich, L.; Schmidpeter, R. Implementing sustainability as the new normal: Responsible management education-From a private business school's perspective. Int. J. Manag. Educ. 2017, 15, 280-292. [CrossRef]

47. Weybrecht, G. From challenge to opportunity: Management education's crucial role in sustainability and the Sustainable Development Goals-An overview and framework. Int. J. Manag. Educ. 2017, 15, 84-92. [CrossRef]

48. Millán, C.; Pérez, Y. Implementación de la Agenda 2030 y los Objetivos de Desarrollo Sostenible en las Universidades Públicas Valencianas. Casos de Estudio: Universitat de València y Universitat Politècnica de València. Available online: https:/cooperacion.umh.es/files/2018/06/Articulo-2.-Implementación-de-laAgenda-2030-y-los-ODS-en-las-Universidades-Públicas-Valencianas.pdf (accessed on 18 May 2020).

49. Zamora-Polo, F.; Sánchez-Martín, J. Teaching for a better world. Sustainability and Sustainable Development Goals in the construction of a change-maker university. Sustainability 2019, 11, 3533. [CrossRef]

50. Annan-Diab, F.; Molinari, C. Interdisciplinarity: Practical approach to advancing education for sustainability and for the Sustainable Development Goals. Int. J. Manag. Educ. 2017, 15, 73-83. [CrossRef] 
51. De la Rosa, D.; Giménez, P.; de la Calle, C. Educación para el desarrollo sostenible: El papel de la universidad en la Agenda 2030. Prism. Soc. 2019, 4, 169-179.

52. Giler, M.A.; Rengel, W.E.; Toapanta, V.A.; Almeida, J.H.; Hurtado, R.F. The Objectives of Sustainable Development (OSD) for education of Tsachila Higher Technological Institute and the strengthening of the commitment with the users. Dilemas Contemp. Educ. Politica Valores 2019, 6, 1-24.

53. Yuan, X.; Zuo, J.; Huisingh, D. Green Universities in China-What matters? J. Clean. Prod. 2013, 61, 36-45. [CrossRef]

54. UN Global Compact Principles for Responsible Management Education. Available online: https://www. unprme.org/what-we-do (accessed on 16 May 2020).

55. Ng, E.S.; Burke, R.J. Predictor of business students' Attitudes toward sustainable business practices. J. Bus. Ethics 2010, 95, 603-615. [CrossRef]

56. Asrar-ul-Haq, M.; Kuchinke, K.P.; Iqbal, A. The relationship between corporate social responsibility, job satisfaction, and organizational commitment: Case of Pakistani higher education. J. Clean. Prod. 2017, 142, 2352-2363. [CrossRef]

57. Holt, D. The role and impact of the business school curriculum in shaping environmental education at Middlesex University. Int. J. Sustain. High. Educ. 2003, 4, 324-343. [CrossRef]

58. Brijlal, P. Entrepreneurial perceptions and knowledge: A survey of final year university students. Afr. J. Bus. Manag. 2011, 5, 818-825.

59. Larrán, M.; Andrades, F.J. Frenos y aceleradores para la implantación de la responsabilidad social en las universidades españolas. Prism. Soc. Rev. Investig. Soc. 2013, 10, 233-270.

60. González-Rodríguez, M.R.; Díaz-Fernández, M.C.; Simonetti, B. Corporative social responsibilities perceptions: An aproximation through Spanish university students' values. Qual. Quant. 2013, 47, 2379-2398. [CrossRef]

61. Brunton, M.; Eweje, G. The influence of culture on ethical perception held by business students in a New Zealand university. Bus. Ethics 2010, 19, 349-362. [CrossRef]

62. Wong, A.; Long, F.; Elankumaran, S. Business students' perception of corporate social responsibility: The United States, China, and India. Corp. Soc. Responsib. Environ. Manag. 2010, 17, 299-310. [CrossRef]

63. Kraft, K.L.; Singhapakdi, A. The relative importance of social responsibility in determining organizational effectiveness: Student responses II. J. Bus. Ethics 1995, 14, 315-326. [CrossRef]

64. Isenmann, R.; Landwehr-Zloch, S.; Zinn, S. Morphological box for ESD-landmark for universities implementing education for sustainable development (ESD). Int. J. Manag. Educ. 2020, 18, 1-15. [CrossRef]

65. Fleacă, E.; Fleacă, B.; Maiduc, S. Aligning strategy with sustainable development goals (SDGs): Process scoping diagram for entrepreneurial higher education institutions (HEIs). Sustainability 2018, 10, 1032. [CrossRef]

66. Albareda-Tiana, S.; Vidal-Raméntol, S.; Pujol-Valls, M.; Fernández-Morilla, M. Holistic approaches to develop sustainability and research competencies in pre-service teacher training. Sustainability 2018, 10, 3698. [CrossRef]

(C) 2020 by the authors. Licensee MDPI, Basel, Switzerland. This article is an open access article distributed under the terms and conditions of the Creative Commons Attribution (CC BY) license (http://creativecommons.org/licenses/by/4.0/). 